\title{
Sap Velocity Studies in Natural Stands of Pinyon and Juniper Trees
}

\section{CONNOR B. SHAW AND GERALD F. GIFFORD}

Highlight: Sap velocities in pinyon (Pinus edulis Engelm.) and juniper (Juniperus osteosperma (Torr.) Little) trees in southeastern and southwestern Utah were studied for 1 year using the heat-pulse technique. Measured velocities were related to nearby environmental factors and Dalton's simplified aerodynamic method for estimating evaporation from water. Sap velocity was independent of the dry weight of green biomass within both pinyon and juniper trees. From 90.5 to $99.0 \%$ and from 66.0 to $99.0 \%$ of the variability in diurnal sap velocities in pinyon and juniper trees, respectively, could be accounted for by using an 8-variable multiple regression equation. Dalton's equation accounted for 4.0 to $86.0 \%$ of the variability in diurnal sap velocities for both tree species on select days. Amount of variability in sap velocities explained by multiple regression equations was reduced markedly when sap velocities and environmental data were pooled over all sampling dates.

Water use by pinyon (Pinus edulis Engelm.) and Utah juniper (Juniperus osteosperma (Torr.) Little) has not received a great deal of attention in the past, despite the fact that much of the Southwest is covered with pinyon-juniper vegetation. Recent studies by Gifford (1975) have indicated that evapotranspiration from pinyon-juniper woodland in southeastern and southwestern Utah is nearly equal to precipitation received. Based on the concept that range improvement practices within most of the pinyon-juniper type should be carried out in a manner which provides for maximum retention of incoming precipitation, it is important that we understand the processes involving water loss from natural woodland so that any hydrologic changes resulting from pinyon-juniper eradication may be correctly interpreted. In Utah, about 12.7 million acres or $23.4 \%$ of the land mass supports some expression of this vegetative type (Dortignac, 1960).

Most plant-water studies in the pinyon-juniper type have been concerned with soil moisture patterns or stream flow as a result of vegetation manipulation (Skau, 1964; Collings and Myrick, 1966; Brown, 1970). Few studies have involved direct measurement of water loss or water movement in either pinyon or juniper trees (Decker and Skau, 1964; Jameson, 1966).

The objective of this study was to examine sap velocities in main stems of both species and to relate the measured

The authors are, respectively, graduate research assistant and associate professor, range hydrology, Range Science Department, College of Natural Resources, Utah State University, Logan, 84322 . This study was in cooperation with the Bureau of Land Management, Contract 14-1 1-0008-2837. Journal Paper No. 1300, Utah Agricultural Experiment Station, Logan.

Manuscript received November 14, 1974. velocities to nearby environmental factors and, in select instances, to a simple model representing evaporation from water. The study is an extension of a study by Skau and Swanson (1963) in which they note the influence of environmental factors on sap velocities in Utah juniper, yet no attempt was made to quantify that influence. In this paper, velocity of a heat pulse as influenced by flow of sap was used to define sap velocities. Heat-pulse velocity, the technically correct term, is used interchangeably with sap velocity.

\section{Methods}

The study was undertaken at two locations: one site is located about $72.5 \mathrm{~km}$ west of Milford in southwestern Utah; the other is located about $72.5 \mathrm{~km}$ west of Blanding in southeastern Utah. The sites have previously been described (Gifford, 1973).

All sap velocities were measured by the heat-pulse technique of Marshall (1958), as modified by Swanson (1967) and Gifford and Frodsham (1971).

Five plants of both tree species were measured hourly from before sunrise to after sunset on selected days (15 at Milford and 13 at Blanding) during 1 year. Tree diameters at $30 \mathrm{~cm}$ height ranged from 25 to $50 \mathrm{~cm}$ with a mean of $37 \mathrm{~cm}$. A 3-0-8-mm probe spacing was used (see Swanson (1967) for details), and two sets of probes were installed in the stem (sapwood) of each tree to a depth of approximately $0.95 \mathrm{~cm}$ at a distance of from 50 to $75 \mathrm{~cm}$ above the soil surface. Minimum detectable sap velocity was $3 \mathrm{~cm} /$ hour.

The green transpiring biomass of each tree was determined by a modification of the method described by Darling (1967). Five pinyon and five juniper trees were sampled from Milford and Blanding combined. After the diameters were taken at the $30 \mathrm{~cm}$ height, the trees were cut down and all green biomass and twigs were removed. Following drying, 15 subsamples $(220 \mathrm{~g} / \mathrm{sample})$ of material were separated into twigs and dry green biomass. Average value for dry green biomass was used to derive total dry weight of material harvested from each tree.

Several environmental parameters were measured at a single location near the trees. Incoming solar radiation was measured with a Yellot-Sol-A-Meter (silicon cell) coupled to a Rustrak recorder. Belford totalizing anemometers were used for wind measurements and a sling psychrometer was used for measuring relative humidities. Temperatures were measured with a standard mercury-in-glass thermometer. The following parameters were examined on both a daily and seasonal (all data pooled) basis in a step-wise multiplc regression analysis (least important variable eliminated first) for their influence on sap movement:

$\mathrm{X}_{1} \quad$ Wind speed at $30 \mathrm{~cm}$ height

$\mathrm{X}_{2} \quad$ Wind speed at midcanopy (about $3.5 \mathrm{~m}$ )

$\mathrm{X}_{3} \quad$ Wind speed at top of canopy (about $7.0 \mathrm{~m}$ )

$\mathrm{X}_{4} \quad$ Soil temperature at $60 \mathrm{~cm}$ soil depth 
$\mathrm{X}_{5} \quad$ Air temperature at $30 \mathrm{~cm}$ height

$\mathrm{X}_{6} \quad$ Air temperature at midcanopy

$\mathrm{X}_{7} \quad$ Air temperature at top of canopy

$\mathrm{X}_{8} \quad$ Incoming shortwave radiation

$\mathrm{X}_{9} \quad$ Relative humidity at $30 \mathrm{~cm}$ height

$\mathrm{X}_{1}$ o Relative humidity at $3.5 \mathrm{~m}$ height

$\mathrm{X}_{11}$ Relative humidity at $7 \mathrm{~m}$ height

Environmental factors were measured on an hourly basis, as were sap velocities.

Besides the multiple regression approach, an attempt was made to relate sap velocities on three selected days to a simplified aerodynamic model used to estimate evaporation from a water surface. The Dalton equation is:

$$
E_{o}=\left(e_{s}-e\right) f(u)
$$

where $\mathbf{e}_{\mathbf{s}}$ is the vapor pressure at the evaporating surface, $\mathbf{e}$ is the vapor pressure at some height about the surface, and $f(u)$ is a function of the horizontal wind velocity. Rohwer (1931) has evaluated the constants in the Dalton equation to give:

$$
\mathrm{E}_{\mathrm{o}}=0.40\left(\mathrm{e}_{\mathrm{s}}-\mathrm{e}_{\mathrm{d}}\right)\left(1+0.17 \mathrm{u}_{2}\right) \mathrm{mm} / \text { day }
$$

In this instance, $e_{s}$ was assumed to be the saturated vapor pressure (though indeed it may be much lower at the surface of transpiring leaves) and $e_{d}$ and $u_{2}$ were integrated values derived from measurements at $30 \mathrm{~cm}, 3.5 \mathrm{~m}$, and $7 \mathrm{~m}$ within the sland of pinyon and juniper. The above equation, though not widely used for estimating transpiration, should provide a rough approximation of the magnitude of physiological control exercised over an otherwise freely evaporating situation.

\section{Results}

\section{Daily Sap Velocity Patterns}

Eleven of 15 measuring dates at Milford had significant hourly fluctuations in sap velocity. At Blanding, 8 of 13 measuring dates had significant hourly fluctuations in sap velocity. Figure 1 is an example of average sap velocities for each species on two dates at Milford. On August 6, 1970, there were significant fluctuations in sap velocity, while on June 23, 1971 , there were no significant fluctuations. The same type of examples are available from the Blanding site. There was some indication that sap velocities were greater in pinyon trees than in juniper trees when soil moisture was high, but this relationship was not consistent.

\section{Sap Velocity vs Green Biomass}

Darling's (1967) studies on pinyon and juniper trees show that as diameter at $30-\mathrm{cm}$ height increases, so does weight of green biomass of the tree. Differences in amount of green biomass between or within species could influence sap velocity.

Figure 2 shows the relationship of dry weight of green biomass to diameter at $30 \mathrm{~cm}$ height of pinyon and juniper trees from both Milford and Blanding. There was no obvious reason for separating either species or sites. A graphical analysis of sap velocities vs tree diameters at $30 \mathrm{~cm}$ height on select dates indicated that within the range of tree diameters encountered in this study, sap velocity was independent of the dry weight of green biomass.

\section{Sap Velocities and Nearby Environment}

\section{Daily Patterns}

Preliminary screening of variables and their relation to sap velocity revealed that three factors $\left(X_{2}, X_{6}, X_{10}\right)$ at approximate midcanopy height could be eliminated.
August 6,1970

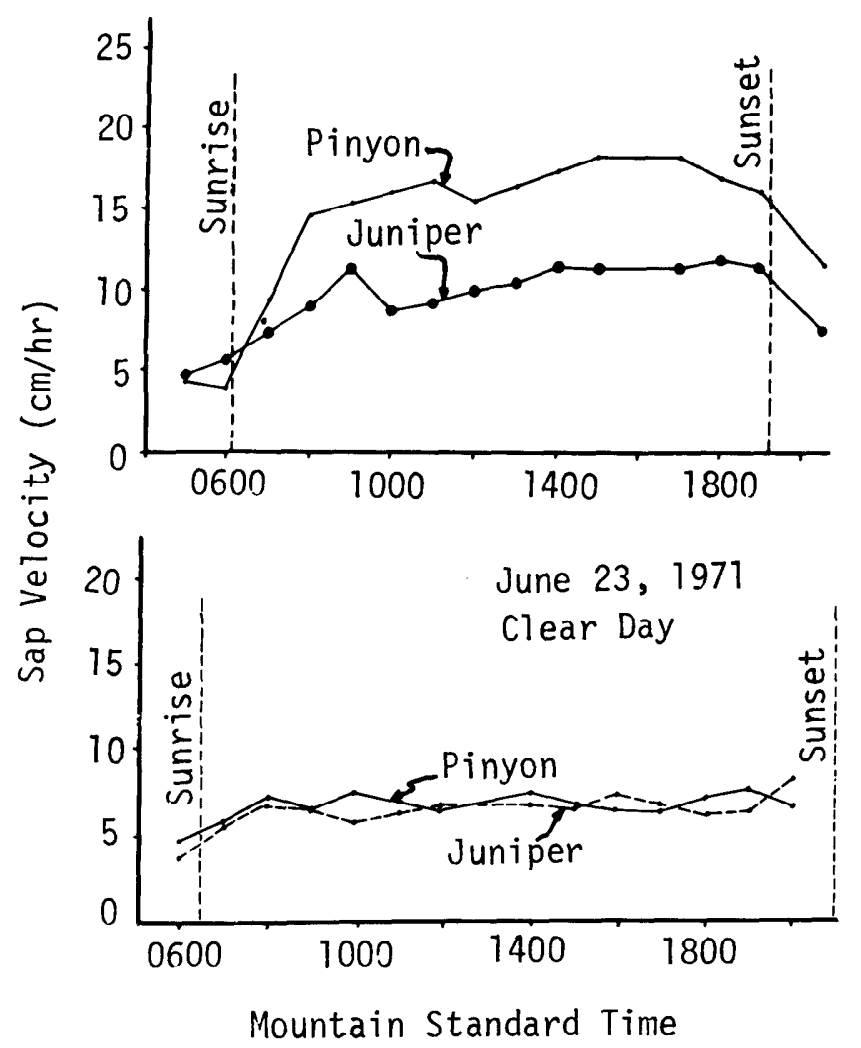

Fig. 1. Average sap velocities for pinyon and juniper on two dates at Milford.

Remaining environmental factors accounted for 90.5 to $93.0 \%$ of the variability in sap velocity of pinyon and between 68.4 and $96.0 \%$ of the variability in sap velocity of juniper at Milford.

At Blanding environmental factors accounted for 92.1 to $99.0 \%$ of the variability in sap velocity of pinyon and for 66.0 to $99.0 \%$ of the variability in sap velocity of juniper.

Evaporation of water as predicted by Dalton's equation explained from 4.0 to $86.0 \%$ of the variability in sap velocities of both species on three select days (August 20,1970, at Milford; August 24, 1970, and June 14, 1971, at Blanding).

\section{All Data Pooled}

Results of pooling data over all sampling dates do not account for much of the variability in sap velocity. At Milford, the 11 -variable multiple regression model explained 37.7 and $26.7 \%$ of the variability associated with sap velocity in juniper and pinyon trees, respectively. Five of 11 variables each explained more than $1 \%$ of the variability in sap velocity of pinyon trees, while 4 of 11 variables explained more than $1 \%$ of the variability in juniper trees. These variables and their relative importance are given in Table 1 .

At Blanding, the 11 -variable multiple regression model explained 31.9 and $29.8 \%$ of the variability associated with sap velocities in pinyon and juniper trees, respectively. Five of 11 variables explained more than $1 \%$ of the variability within both species (Table 1).

\section{Discussion}

Significant hourly fluctuations in sap velocity occurred on $68 \%$ of the 28 measuring dates at the two sites. Size of tree did not influence sap velocities, which were independent of the 


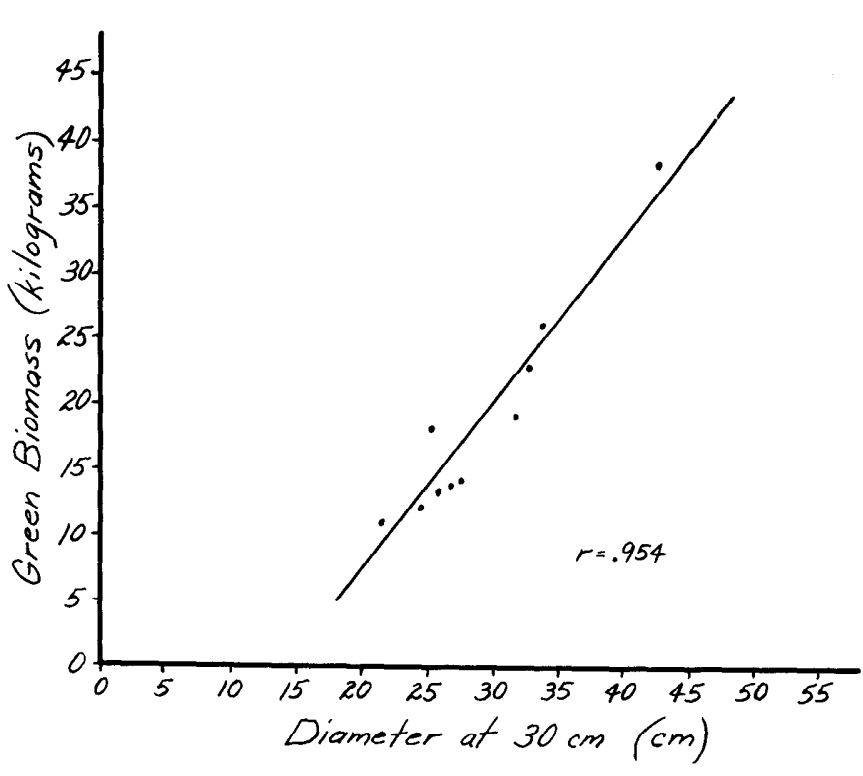

Fig. 2. Relationship of dry green biomass to diamter at $30 \mathrm{~cm}$ height for both pinyon and juniper trees. Equation of the line is $Y=-18.67$ $+1.28(X)$.

dry weight of green biomass. This may be entirely reasonable, since larger trees would be expected to have increased root surface and conducting (sapwood) area in the bole as well as increased green biomass. Assuming the proportion stayed the same, then sap velocities would be expected to remain somewhat constant. Total root surface and conducting area of each tree was not, however, examined in this study.

Nearby environmental factors accounted for up to $99.0 \%$ of the variability in sap velocities of both pinyon and juniper trees on a diurnal basis. Environmental factors generally accounted for a greater amount of variability in sap rates of pinyon than in sap rates of juniper. This is of interest because Jameson (1966) found no correlation of foliage moisture content of pinyons with meteorological conditions. $\mathrm{He}$ concluded that pinyon leaves have some mechanism to retard the rate of moisture loss that would otherwise occur during summer days, while the mechanism in junipers is not fully adequate. This study suggests that such a conclusion may not be entirely valid, and may in fact be just the reverse.

Table 1. Variables explaining more than $1 \%$ of the variability in sap velocities in either juniper or pinyon at the Milford and Blanding study sites (data from all sampling dates pooled).

\begin{tabular}{clcc}
\hline & & \multicolumn{2}{c}{ Percent variance explained } \\
\cline { 3 - 4 } Variable & \multicolumn{1}{c}{ Description } & Pinyon & Juniper \\
\hline Milford & & & \\
$\mathrm{X}_{1}$ & Wind speed at $30 \mathrm{~cm}$ & 1.4 & \\
$\mathrm{X}_{2}$ & Wind speed at $3.5 \mathrm{~m}$ & 3.2 & 2.3 \\
$\mathrm{X}_{5}$ & Air temp. at $30 \mathrm{~cm}$ & & 7.2 \\
$\mathrm{X}_{8}$ & Shortwave radiation & 15.0 & 25.8 \\
$\mathrm{X}_{9}$ & Relative humidity at $30 \mathrm{~cm}$ & & \\
$\mathrm{X}_{10}$ & Relative humidity at $3.5 \mathrm{~m}$ & 1.1 & 1.1 \\
$\mathrm{X}_{11}$ & Relative humidity at $7 \mathrm{~m}$ & 3.2 & \\
Blanding & & & \\
$\mathrm{X}_{1}$ & Wind speed at $30 \mathrm{~cm}$ & 15.1 & 6.2 \\
$\mathrm{X}_{2}$ & Wind speed at $3.5 \mathrm{~m}$ & & 1.6 \\
$\mathrm{X}_{3}$ & Wind speed at $7 \mathrm{~m}$ & 1.8 & 10.8 \\
$\mathrm{X}_{6}$ & Air temp. at $3.5 \mathrm{~m}$ & 3.1 & \\
$\mathrm{X}_{7}$ & Air temp. at $7 \mathrm{~m}$ & 1.3 & 5.3 \\
$\mathrm{X}_{10}$ & Relative humidity at $3.5 \mathrm{~m}$ & 8.6 & 2.1 \\
\hline
\end{tabular}

Pooling data over all sampling dates resulted in large reductions in amount of explained variability associated with sap velocities in both the pinyon and the juniper trees. This is not surprising as seasonal changes, soil moisture stress, etc., may all interact over time to increase the variability of sap velocities for any given environmental input.

Based on the work by Skau and Swanson (1963), it can be assumed that sap velocity is an excellent indication of water being transpired (evaporated), at least from Utah juniper. Results from this study, utilizing Dalton's equation, hint strongly of some degree of physiological regulation (stomatal control) of water loss from the two tree species. However, further insight on the importance of this mechanism will have to await controlled studies of internal water relations within the trees.

In summary, a potential for water loss via transpiration exists in both pinyon and juniper throughout all 12 months of a year. In contrast, when the trees are replaced by grasses, transpiration potentials are high only during active growth periods of the grasses. Soil moisture studies on these same sites (Gifford and Shaw, 1973) have shown that removal of the trees may result in increased soil moisture during part or all of a year. The increase is noted primarily at soil depths below 60 $\mathrm{cm}$. The fact that roots of pinyon and juniper extend beyond $60 \mathrm{~cm}$ depth and also that water loss from the trees is continually responsive not only to availability of moisture but also to a high atmospheric evaporative demand, then it is little wonder that soil moisture values under natural woodland are comparatively low throughout the year.

\section{Literature Cited}

Brown, H. E. 1970. Status of pilot watershed studies in Arizona. A.S.C.E. Proc., J. Irrig. and Drainage Div. 96:11-23.

Collings, M. R., and R. M. Myrick. 1966. Effects of juniper and piny on eradication on streamflow from Corduroy Creek Basin, Arizona. U.S. Geol. Surv. Prof.

Darling, M. L. S. 1967. Structure and productivity of a pinyon-juniper woodland in northern Arizona. PhD Diss., Duke University. $170 \mathrm{p}$.

Decker, J. P., and C. M. Skau. 1964. Simultaneous studies of transpiration rate and sap velocity in trees. Plant Physiol. 39:213-215.

Dortignac, E. J. 1960. Water yield from pinyon-juniper woodland. In Water Yield in Relation to Environment in the Southwestern United States, Proc. Amer. Assoc. Adv. Sci. Symp., Sul Ross State College, Mary 3:16-27.

Gifford, G. F. 1973. Runoff and sediment yields from runoff plots on chained pinyon-juniper sites in Utah. J. Range Manage. 26:440-443.

Gifford, G. F. 1975. Approximate annual water budgets for two chained pinyon-juniper sites. J. Range Manage. 28:73-74.

Gifford, G. F., and G. D. Frodsham. 1971. Improved heat pulse velocity meter. J. Range Manage. 24:469-470.

Gifford, G. F., and C. B. Shaw. 1973. Soil moisture patterns on two chained pinyon-juniper sites in Utah. J. Range Manage. 26:436-440.

Jameson, D. A. 1966. Diurnal and seasonal fluctuations in moisture content of pinyon and juniper. U.S. Forest Serv. Res. Note RM-67. $7 \mathrm{p}$.

Marshall, D. C. 1958. Measurement of sap flow in conifers by heat transport. Plant Physiol. 33:385-396.

Rohwer, C. 1931. Evaporation from free water surface. U.S. Dep. Agr, Tech Bull. 271. $96 \mathrm{p}$.

Skau, C. M. 1964. Soil water storage under natural and cleared stands of alligator and Utah juniper in northern Arizona. U.S. Forest Res. Note RM-24. 3 p.

Skau, C. M., and R. H. Swanson. 1963. An improved heat pulse velocity meter as an indicator of sap speed and transpiration. J. Geophys. Res. 68:4743-4749.

Swanson, R. H. 1967. Seasonal course of transpiration of lodgepole pine and Engelmann spruce. Also, Appendixes to above paper. In Proc. Intern. Symp. on Forest Hydrology, Penn. Statc Univ., Aug. 29-Sept. 10, 1965. p. 417-432. 